\title{
Complement proteins in unexpected places: why we should be excited, not concerned! [version 1; peer review: 2
}

\section{approved]}

\section{Berhane Ghebrehiwet}

Department of Medicine, Stony Brook University, Stony Brook, New York, 11794-0001, USA

V1 First published: 26 Feb 2020, 9(F1000 Faculty Rev):149

https://doi.org/10.12688/f1000research.21690.1

Latest published: 26 Feb 2020, 9(F1000 Faculty Rev):149

https://doi.org/10.12688/f1000research.21690.1

\section{Abstract}

The complement system consists of more than 30 plasma as well as cell surface proteins that together constitute a major arm of the immune system. The long-held belief is that most of the complement components are synthesized by hepatocytes in the liver and then secreted into the blood. However, there is also substantial evidence that several if not all of the complement proteins are synthesized extrahepatically by a wide range of cell types, including polymorphonuclear leukocytes, monocytes, macrophages, dendritic cells, lymphocytes, epithelial cells, fibroblasts, and neuronal cells. However, despite the proven evidence that complement proteins indeed could be synthesized non-hepatic cells and even found in unexpected places, the recent finding that certain complement proteins could be activated in intracellular spaces nonetheless has opened up a new debate. In fact, some in the field unfortunately seem to be in favor of rejecting this notion rather vehemently on the untenable and myopic grounds that complement proteins could not be found in intracellular compartments despite evidence to the contrary. Therefore, this opinion article is meant to remind colleagues in the field that new discoveries with the potential to shift established functional paradigms should be encouraged and celebrated even if, at first glance, they seem to defy the odds.

\section{Keywords}

Complosome, intracellular complement

\section{Open Peer Review}

Approval Status

1

2

version 1

26 Feb 2020

Faculty Reviews are review articles written by the prestigious Members of Faculty Opinions. The articles are commissioned and peer reviewed before publication to ensure that the final, published version is comprehensive and accessible. The reviewers who approved the final version are listed with their names and affiliations.

1. Peter J Lachmann, University of Cambridge, Cambridge, UK

2. John Atkinson, Washington University

School of Medicine, Saint Louis, USA

Any comments on the article can be found at the end of the article. 
Corresponding author: Berhane Ghebrehiwet (berhane.ghebrehiwet@stonybrook.edu)

Author roles: Ghebrehiwet B: Writing - Original Draft Preparation

Competing interests: No competing interests were disclosed.

Grant information: The work included in this article was supported in part by grants from the National Institutes of Allergy and Infectious Diseases R01 AI 060866 and R01 AI-084178, R56 AI-122376 (to BG).

The funders had no role in study design, data collection and analysis, decision to publish, or preparation of the manuscript.

Copyright: $\odot 2020$ Ghebrehiwet B. This is an open access article distributed under the terms of the Creative Commons Attribution License, which permits unrestricted use, distribution, and reproduction in any medium, provided the original work is properly cited.

How to cite this article: Ghebrehiwet B. Complement proteins in unexpected places: why we should be excited, not concerned! [version 1; peer review: 2 approved] F1000Research 2020, 9(F1000 Faculty Rev):149 https://doi.org/10.12688/f1000research.21690.1

First published: 26 Feb 2020, 9(F1000 Faculty Rev):149 https://doi.org/10.12688/f1000research.21690.1 


\section{Introduction}

For any student of the biological sciences-or any of the sciences for that matter-nothing is more thrilling than the identification of a new molecule or a new pathway, since either potentially heralds the unraveling of a heretofore unrecorded or unanticipated biological function. However, such excitement sometimes is dampened by a few polemicists in the given field who reject or challenge the veracity of a new discovery outright on the basis of a post hoc ergo propter hoc logic. This logic stipulates that the location and function of each protein in our system are already known, ergo the presence of any protein outside its established locale must be an anomaly. This logic is, of course, erroneous because it is based on the false premise that plasma proteins are found in plasma and intracellular proteins are found only inside the cell and not anywhere else. This, in fact, is not true. Indeed, members of all classes of proteinscytoskeletal components, secreted growth factors, glycolytic enzymes, kinases, transcription factors, chaperones, transmembrane proteins, and extracellular matrix proteins-have been identified in cellular compartments other than their conventional sites of action ${ }^{1,2}$. Furthermore, even highly conserved mitochondrial proteins are now being found performing novel extramitochondrial functions in unexpected extramitochondrial sites. This would suggest that mitochondrial proteins not only possess novel mechanisms for protein export to other sites ${ }^{2}$ but also may have distinct novel roles in each compartment-be it intracellular or extracellular. This would suggest that each has the potential to participate in a variety of health and disease processes. Similarly, if proteins that should not be expected inside the cell are found inside the cell, then there must be a logical and functional reason why the protein is there, and it is for us to dig down and investigate.

Rational controversy or healthy disagreement in any field of science is part of the maturation and solidification process and therefore should be encouraged. But hasty, illogical, and dogmatic critique should be avoided lest it discourage those who have the courage to look outside the box to show us that novel paradigms could be unraveled if we look, without bias, deeper in unexpected places. Indeed, that is what research should be all about. Yet instead of challenging or encouraging these bright and daring scientists to generate more data to prove their cases, we often consciously or unconsciously discourage them by rejecting their proposed premise outright without a leg to stand on. Indeed, rejection and controversy are not new to any branch of science, least of all the complement field. In fact, some of the best ideas and discoveries, including Einstein's, have been mistakenly rejected ${ }^{3,4}$. However, a hasty and reckless rejection unfortunately has far-reaching professional and personal consequences. First, the same people who reject the novel concept unfortunately also happen to be the ones who review and reject the manuscripts submitted for publication. Second-and psychologically more damaging-is the fact that these skeptics or other like-minded individuals also sit on many grant review panels and literally trash such a proposal when submitted for funding to agencies such as the National Institutes of Health. The list of brilliant ideas that were rejected and consequently never saw the light of day is too long to provide here. Fortunately, some discoveries have also stood the test of time, largely due to the undying courage and selfconfidence of the proponents. However, it should be mentioned that the kind of unfair rejection and the inability to procure funding are, in fact, what drive many a bright and aspiring young scientist to abandon his or her project - and sometimes even the very science they love-in disgust. Therefore, if we are to advance real science, a rush to harsh judgment should be avoided; instead, we should challenge the primary investigator to generate more data to prove his or her premise. In fact, we know from experience that not every novelty turns out to be right. But once it is solidly proven wrong, no one else has to fall into the same trap again. This kind of attitude could only encourage the young flag-bearers or even the seasoned scientists to be more productive and inventive.

\section{Complement proteins in unexpected places: novel concepts and shifting paradigms}

The complement system, like any of the other biological sciences, is not new to controversy. Since the discovery of complement by Buchner in the late 19th century ${ }^{5}$, the description of each of the more than 30 proteins that make up the complement system and the three independent pathways has had its share of formidable challenges and controversies. No one has suffered the "slings and arrows" of painful rejection more than the brilliant scientist, Louis Pillemer ${ }^{6,7}$. Although he was the genius behind the discovery of the properdin (alternative) pathway-in addition to many other seminal contributions to the field-his discovery was not well received by his contemporaries, whose rationale was that a complement pathway (at that time, only the "C1 pathway" was recognized) that does not require antibody for activation would be impossible to comprehend ${ }^{6-8}$. Even in this day and age of sophisticated technology where one can prove or disprove a particular scientific question overnight, individual scientists find it easier to reject a novel concept outright if it does not satisfy their preconceived notion of what the concept should be than to give the proponent a chance to prove the concept.

One of the most exciting discoveries of the past few years is the finding of key complement proteins such as C3 and C5 in the intracellular compartment of $\mathrm{T}$ cells. These proteins in turn can be activated intracellularly and cross-talk with the inflammasome. According to this novel concept, $\mathrm{T}$ cells contain endosomal and lysosomal pools of $\mathrm{C} 3$, which can be processed into biologically active $\mathrm{C} 3 \mathrm{a}$ and $\mathrm{C} 3 \mathrm{~b}$ by the $\mathrm{T}$ cell cathepsin $^{9-11}$. These active fragments in turn serve the cell for homeostatic survival, whereas translocation of these fragments may induce autocrine pro-inflammatory cytokine production ${ }^{9-11}$. However, although this novel function of C3 and C5 in homeostatic survival of $\mathrm{T}$ cells is very exciting, one has to address the concern of those who might say, "If this is the mechanism of T-cell survival, why doesn't genetic deficiency of the entire C3 gene in mice or humans lead to T-cell failure?". In fact, many animal disease models seem to show that genetic deficiency in C3 does not exacerbate the disease process, suggesting that the mechanism might be different ${ }^{12,13}$. 
The presence of complement proteins inside the cell, in and of itself, is not a novel observation since the existence of intracellular $\mathrm{C}$ proteins inside both immune and non-immune cells has been documented before ${ }^{14-18}$. In fact, almost all types of cells are known to synthesize complement proteins, some of which are stored inside the cell. However, it is the discovery of the existence of a crosstalk between intracellular complement and the inflammasome that has ignited excitement in the field. This novel concept has a name: it is called the "complosome"'? This discovery was not appreciated by a few in the field, some of whom expressed their open disagreement at the XXVI International Complement Workshop, even though a whole session of the workshop (held in Kanazawa City, Japan, in 2016) was assigned to complosome. But it is surprising and difficult to understand how the veracity and relevance of intracellular complement proteins are still being questioned despite the robust evidence that has been accumulated to date. Not surprisingly, the significance of intracellular complement was again discussed under the title "What do we mean by intracellular complement?" at the 17th European Meeting on Complement in Human Disease (EMCHD) held recently in Madrid. However, the fact that it was brought up again for discussion supports the tenet that the function of intracellular complement has finally sparked the interest it deserves since the questions that were being asked were legitimate and appropriate. Therefore, we anticipate that this new area of research will remain a mainstay for the near future, as it would help us understand how intracellular complement proteins cross-talk with molecules of the inflammasome and potentially other intracellular proteins in both health and disease.

As mentioned above, several laboratories have shown the presence of complement or complement-like proteins inside the cell $^{14,16,17}$. The human neutrophils, for example, contain intracellular stores of CR1, C3, FB, and properdin ${ }^{14}$. Upon neutrophil activation, the surface CR1 increases from a few thousand to 30,000 to 50,000 per cell. In addition, FB, properdin, and C3 are released from stores to trigger a local inflammatory process. Whether this process involves a traditional cascade reaction or simple proteolysis to release functionally active fragments such as $\mathrm{C} 3 \mathrm{a}$ or $\mathrm{Ba}$ is not yet known. Similarly, the presence of C1q or C1q-like proteins has been shown in cell lysates ${ }^{15,18,19}$, although the structure of the chains, especially the A-chain, appears to be different than that of the A-chain of C1q purified from plasma ${ }^{18}$. More interestingly, the presence of $\mathrm{C} 1 \mathrm{q}$ globular domain $(\mathrm{gClqD})$ inside the cell is well documented ${ }^{20}$. The $\mathrm{C} 1 \mathrm{q}$ molecule is a member of the tumor necrosis factor alpha $(\mathrm{TNF} \alpha)$ superfamily of proteins, which includes adiponectin, and contains a "gC1qD" domain — a highly conserved domainfound in most of the TNF $\alpha$ superfamily of proteins ${ }^{21}$. Furthermore, both the receptor for the $\mathrm{gClqD}$, called $\mathrm{gClqR}$, and the receptor for the collagen domain, called $\mathrm{cClqR}$ or calreticulin (CRT), are also found in many compartments inside the cell ${ }^{22,23}$. Although the exact function of these proteins has yet to be elucidated, it is plausible to assume that an interaction between intracellular $\mathrm{Clq}$ or $\mathrm{gClqD}$ and its receptor $\mathrm{gC} 1 \mathrm{qR}$, similar to those described for $\mathrm{C} 3^{24,25}$, exists inside the cell and is potentially involved in either apoptosis or cell proliferation. Therefore, understanding of the interaction between these intracellular complement proteins and other molecules may reveal unexpected functions with the potential to unlock some biological mysteries of health and disease.

Finally, as the discussants at the recent EMCHD suggested, the structure as well as the function of the plasma complement proteins and their intracellular homologues might indeed differ because of post-translational modifications or enzymatic cleavages. Like those of $\mathrm{gC} 1 \mathrm{qD}$, the structure and function of intracellular C3 and C5 may have been designed for purposes other than complement activation. Therefore, it would not be unreasonable to assume that different versions or structures of the same molecule may exist intracellularly for the purpose of fulfilling currently unrecognized functions. But the existence of complement proteins inside the cell should not be in dispute anymore. Therefore, it behooves us to encourage and support the pioneers in this area who had the foresight to think outside the box and unravel novel locations and functions of complement proteins. Like many earlier discoveries that-despite the initial antagonism-have enriched the complement field, the discovery of complement proteins inside the cell should now open a new chapter in the ever-growing and fascinating field that is complement. Discovery in science is like a river in that "the water that you see is the last of what has gone but is the first of what is to come". Therefore, we should hope that we are able to see, for the best is yet to come!

\section{Conclusions}

Controversy in science is not unique. Most of the great biomedical discoveries that we now take for granted were initially met with outright skepticism and rejection. Indeed, it would have stayed as such had it not been for the brave few who fought back to prove that their observations or discoveries were indeed correct. Some of the brave and self-confident ones had to go to extraordinary lengths: Barry Marshall drank broth containing Helicobacter pylori-when the animal studies did not work-to provide evidence that this bacterium was indeed the cause of peptic ulcer. Although in the end he was recognized for his pioneering work by winning the Nobel Prize in 2005, he would not have had to go through such a risky experiment had his colleagues believed him in the first place. From Barry Marshall to Peyton Rous, the discoverer of the virus that now bears his name, many a brilliant scientist had to suffer unfair rejection before he or she was finally recognized. However, in the words attributed to Winston Churchill: "Success is not final and failure is not fatal, it is the courage to continue that counts". And despite all the ephemeral fuss, continue we should! It may take a while before we figure out the significance of complement proteins inside the cell, but it is time we give this nascent area of complosome the applause and recognition it greatly deserves. 
1. Smalheiser NR: Proteins in unexpected locations. Mol Biol Cell. 1996; 7(7): 1003-14. PubMed Abstract | Publisher Full Text | Free Full Text

2. Soltys BJ, Gupta RS: Mitochondrial proteins at unexpected cellular locations: export of proteins from mitochondria from an evolutionary perspective. Int Rev Cytol. 2000; 194: 133-96.

PubMed Abstract | Publisher Full Text

3. Katz Y: Why are scientists so fascinated by rejection? Scientific Amer. 2016. Reference Source

4. F Fathelrahman Al: Rejection of Good Manuscripts: Possible Reasons, Consequences and Solutions. J Clinic Res Bioeth. 2015; 6(1). Publisher Full Text | F1000 Recommendation

5. Buchner H: Zur Nomenklatur der schutzenden Eiweisskorper. Centr Bakteriol Parasitenk. 1891; 10: 699-701.

6. Ratnoff WD: A war with the molecules: Louis Pillemer and the history of properdin. Perspect Biol Med. 1980; 23(4): 638-57. PubMed Abstract | Publisher Full Text

7. F Lachmann PJ: Looking back on the alternative complement pathway. Immunobiology. 2018; 223(8-9): 519-23.

PubMed Abstract | Publisher Full Text | F1000 Recommendation

8. Lepow IH: Presidential address to American Association of Immunologists in Anaheim, California, April 16, 1980. Louis Pillemer, Properdin, and scientific controversy. J Immunol. 1980; 125(2): 471-5. PubMed Abstract

9. F Arbore G, Kemper C, Kolev M: Intracellular complement - the complosome - in immune cell regulation. Mol Immunol. 2017; 89: 2-9. PubMed Abstract | Publisher Full Text | F1000 Recommendation

10. F Kolev M, Kemper C: Keeping It All Going-Complement Meets Metabolism. Front Immunol. 2017; 8: 1.

PubMed Abstract | Publisher Full Text | Free Full Text | F1000 Recommendation

11. F Liszewski MK, Kolev M, Le Friec G, et al.: Intracellular complement activation sustains $\mathrm{T}$ cell homeostasis and mediates effector differentiation. Immunity. 2013; 39(6): 1143-57.

PubMed Abstract | Publisher Full Text | Free Full Text | F1000 Recommendation

12. F Larkin PB, Muchowski PJ: Genetic Deficiency of Complement Component 3 does not Alter Disease Progression in a Mouse Model of Huntington's Disease. J Huntingtons Dis. 2012; 1(1): 107-18.

PubMed Abstract | Publisher Full Text | Free Full Text | F1000 Recommendation

13. Sekine H, Reilly CM, Molano ID, et al.: Complement component C3 is not required for full expression of immune complex glomerulonephritis in MRL/Ipr mice. J Immunol. 2001; 166(10): 6444-51. PubMed Abstract | Publisher Full Text

14. F Lubbers R, van Essen MF, van Kooten C, et al.: Production of complement components by cells of the immune system. Clin Exp Immunol. 2017; 188(2) 183-94.

PubMed Abstract | Publisher Full Text | Free Full Text | F1000 Recommendation

15. $F$ van Schaarenburg RA, Suurmond J, Habets KL, et al.: The production and secretion of complement component $\mathrm{C} 1 \mathrm{q}$ by human mast cells. Mol Immunol. 2016; 78: 164-70.

PubMed Abstract | Publisher Full Text | F1000 Recommendation

16. Botto $M$, Lissandrini $D$, Sorio $C$, et al.: Biosynthesis and secretion of complement component (C3) by activated human polymorphonuclear leukocytes. J Immunol. 1992; 149(4): 1348-55.

PubMed Abstract

17. Thomas A, Gasque P, Vaudry D, et al.: Expression of a complete and functional complement system by human neuronal cells in vitro. Int Immunol. 2000; 12(7): 1015-23.

PubMed Abstract | Publisher Full Text

18. Kandov E, Kaur A, Kishore $\mathrm{U}$, et al.: $\mathrm{C} 1 \mathrm{q}$ and $\mathrm{C} 1 \mathrm{q}$ receptors (gC1qR and $\mathrm{cC} 1 \mathrm{qR}$ ) as potential novel targets for therapy against breast cancer. Curr Trends Immunol. 2018; 19: 59-76. Reference Source

19. Rabs $\mathrm{U}$, Martin $\mathrm{H}$, Hitschold $\mathrm{T}$, et al:: Isolation and characterization of macrophage-derived C1q and its similarities to serum C1q. Eur J Immunol. 1986; 16(9): 1183-6.

PubMed Abstract | Publisher Full Text

20. Innamorati G, Bianchi E, Whang MI: An intracellular role for the C1q-globular domain. Cell Signal. 2006; 18(6): 761-70.

PubMed Abstract | Publisher Full Text

21. Kishore U, Gaboriaud C, Waters $P$, et al.: $\mathrm{C} 1 \mathrm{q}$ and tumor necrosis factor superfamily: modularity and versatility. Trends Immunol. 2004; 25(10): 551-61. PubMed Abstract | Publisher Full Text

22. Ghebrehiwet B, Geisbrecht BV, Xu X, et al.: The C1q Receptors: Focus on gC1qR/p33 (C1qBP, p32, HABP-1)'. Semin Immunol. 2019; 45: 101338. PubMed Abstract | Publisher Full Text

23. Dedio J, Jahnen-Dechent W, Bachmann M, et al.: The multiligand-binding protein gC1qR, putative C1q receptor, is a mitochondrial protein. J Immunol. 1998; 160(7): 3534-42. PubMed Abstract

24. F Cravedi $P$, Leventhal J, Lakhani $P$, et al.: Immune cell-derived C3a and C5a costimulate human T cell alloimmunity. Am J Transplant. 2013; 13(10): 2530-9. PubMed Abstract | Publisher Full Text | Free Full Text | F1000 Recommendation

25. F Satyam A, Kannan L, Matsumoto N, et al:: Intracellular Activation of Complement 3 Is Responsible for Intestinal Tissue Damage during Mesenteric Ischemia. J Immunol. 2017; 198(2): 788-97.

PubMed Abstract | Publisher Full Text | F1000 Recommendation 


\section{Open Peer Review}

\section{Current Peer Review Status:}

\section{Editorial Note on the Review Process}

Faculty Reviews are review articles written by the prestigious Members of Faculty Opinions. The articles are commissioned and peer reviewed before publication to ensure that the final, published version is comprehensive and accessible. The reviewers who approved the final version are listed with their names and affiliations.

\section{The reviewers who approved this article are:}

\section{Version 1}

\section{John Atkinson}

Division of Rheumatology, Department of Medicine, Washington University School of Medicine, Saint Louis, Missouri, USA

Competing Interests: No competing interests were disclosed.

\section{Peter J Lachmann}

Department of Veterinary Medicine, University of Cambridge, Cambridge, UK

Competing Interests: No competing interests were disclosed.

The benefits of publishing with F1000Research:

- Your article is published within days, with no editorial bias

- You can publish traditional articles, null/negative results, case reports, data notes and more

- The peer review process is transparent and collaborative

- Your article is indexed in PubMed after passing peer review

- Dedicated customer support at every stage

For pre-submission enquiries, contact research@f1000.com 